\title{
STRATEGI PENGEMBANGAN BADAN USAHA MILIK DESA (BUMDES) DI KABUPATEN SINJAI (STUDI KASUS DESA POLEWALI)
}

\author{
The Development Strategies of Village-Owned Enterprise (BUMDes) in Sinjai Regency: A Case Study \\ of Polewali Village
}

\author{
Mazlan $^{1}$, Imran Ismail ${ }^{2}$, Juharni $^{2}$ \\ ${ }^{1}$ Magister Ilmu Administrasi Negara Program Pascasarjana Universitas Bosowa \\ ${ }^{2}$ Program Studi Ilmu Administrasi Negara Program Pascasarjana Universitas Bosowa
}

Email: mazlanpaturusi94@gmail.com

Diterima: 03 Januari 2020

Dipublikasikan: 05 Juni 2020

\begin{abstract}
ABSTRAK
Pengembangan kawasan pedesaan memiliki peran penting dalam mendukung pembangunan nasional. oleh karena itu, pengembangan diarahkan dalam pemanfaatan sumber daya yang ada. Diharapkan dapat mengurangi ketergantungan terhadap kota. BUMDes Polewali Maju menjadi salah satu bagian dalam proses pemanfaatan sumber daya yang ada. Penelitian ini bertujuan untuk (1) Mengetahui sistem pelaksanaan pengelolaan BUMDes Polewali Maju di Desa Polewali Kabupaten Sinjai dan (2) Mengetahui cara meningkatkan pengembahan usaha BUMDes Polewali Maju di Desa Polewali Kabupaten Sinjai. Penelitian ini menggunakan pendekatan diskriptif kualitatif, subyek penelitian ini adalah BUMDes Polewali Maju, dengan informan kunci adalah Direktur BUMDes, dan informan adalah Kepala Desa, staf BUMDes, Kepala Dinas PMD Sinjai dan Kabid PMD Sinjai. Hasil penelitian menunjukkan (1) Pelaksanaan pengelolaan BUMDes Polewali Maju dilakukan berdasarkan regulasi yang mengatur, seperti proses pembentukan kelembagaan dan ketersediaan sarana dan prasarana. (2) Cara mengembangkan usaha BUMDes Polewali Maju dilakukan melalui interpensi keuangan (Permodalan) dari pemerintah Desa Polewali, memberdayakan masyarakat untuk ikut serta dalam pengembangan BUMDes, membina masyarakat dan petugas BUMDes melalui pelatihan dan pendampingan serta mengembangkan kemitraan dengan para pihak yang bertujuan untuk membantu pemasarean hasil produksi BUMDes Polewali Maju yaitu produk air minum kemasan. Kesimpulan dari hasil penelitian adalah bahwa pelaksanaan pengelolaan BUMDes di Desa Polewali sudah dilakukan sesuai dengan peraturan yang berlaku dan tata kerja yang telah dibuat bersama antar seluruh pihak terkait dengan BUMDes Polewali Maju. Penentuan kelembagaan BUMDes juga dilakukan dengan baik karna sudah tidak melibatkan perangkat Desa. Hanya saja kelegkapansaran dan prasaranan BUMDes masih sangat terbatas. Sementara berkaitan dengan cara pengembangan usaha BUMDes masih belum produktif, seperti kerja sama dengan para pihak, pelatihan dan pendampingan yang minim.
\end{abstract}

Kata Kunci: Pengembangan, Pengelolaan, BUMDes, Sinjai

\begin{abstract}
Rural area development has an important role in supporting national development. Therefore, development is directed towards the utilization of available resources. It is expected to reduce the dependence on the city. Polewali Maju BUMDes is one part of the process of utilizing existing resources. This study aims to: (1) Know the implementation system of Polewali Maju BUMDes management in Polewali Village, Sinjai Regency; and (2) Know how to increase Polewali Maju BUMDes business development in Polewali Village, Sinjai Regency. This study used a qualitative descriptive approach, the subjects of this study were BUMDes Polewali Maju, and the key informants were BUMDes Directors, Village Heads, BUMDes staff, Sinjai PMD Office Heads and Sinjai PMD Heads. The results showed that: (1) The implementation of the Polewali Maju BUMDes management was carried out based on the regulations that govern it, such as the process of institutional formation and the availability of facilities and infrastructure. (2) How to develop BUMDes Polewali Maju business is done through financial interventions (Capital) from the Polewali Village government, empowering the community to participate in BUMDes development, fostering community and BUMDes officers through training and mentoring and developing partnerships with parties aiming to assist in supplying Polewali Maju's BUMDes production results, which are bottled water products. The conclusion from the results of the study is that the implementation of BUMDes management in Polewali Village has been carried out in accordance with applicable regulations and work procedures that have been made jointly between all parties related to Polewali Maju BUMDes. The determination of BUMDes institutions is also done well because it does not involve village officials. However, the facilities and infrastructures of BUMDes are still very limited. Meanwhile, related to the business development, BUMDes is still not productive, such as cooperation with the parties, training and assistance that are minimal.
\end{abstract}

Keywords: Development, Management, BUMDes, Sinjai

\section{PENDAHULUAN}

Negara Pengembangan basis ekonomi di pedesaan sudah semenjak lama dijalankan oleh pemerintah melalui berbagai program. Namun, upaya itu belum membuahkan hasil yang memuaskan sebagaimana diinginkan bersama. Terdapat banyak faktor yang menyebabkan kurang 
berhasilnya program-program tersebut. Salah satu faktor yang paling dominan adalah intervensi pemerintah yang terlalu besar, akibatnya justru menghambat daya kreativitas dan inovasi masyarakat desa dalam mengelola dan menjalankan mesin ekonomi di pedesaan (Ridwan $e t$ al., 2019). Sistem dan mekanisme kelembagaan ekonomi di pedesaan tidak berjalan efektif dan berimplikasi pada ketergantungan terhadap bantuan pemerintah sehingga mematikan semangat kemandirian. Untuk mewujudkan desa yang mandiri, maka diperlukan sumber pendapatan bagi desa yang berasal dari desa tersebut. Kemandirian yang dimaksud adalah proses yang dilakukan pemerintah desa bersama masyarakat untuk melakukan kegiatan dalam rangka pemenuhan kebutuhannya sesuai kemampuan yang dimiliki. Dalam mendorong pembangunan ditingkat desa, pemerintah memberikan kewenangan kepada pemerintah desa untuk mengelola daerahnya secara mandiri, salah satunya adalah melalui lembaga ekonomi yang berada ditingkat desa yakni Badan Usaha Milik Desa yang selanjutnya disingkat BUMDes (Coristya, 2016).

Badan Usaha Milik Desa (BUMDes) merupakan lembaga usaha desa yang dikelola oleh masyarakat dan pemerintahan desa dalam upaya memperkuat perekonomian desa dan dibentuk berdasarkan kebutuhan dan potensi desa. BUMDes diharapkan mampu menstimuli dan menggerakkan roda perekonomian di pedesaan. Asset ekonomi yang ada di desa harus dikelola sepenuhnya oleh masyarakat desa. Peranan Badan Usaha Milik Desa (BUMDes) terhadap peningkatan perekonomian desa, Menurut (Seyadi, 2003) bahwa untuk pembangunan dan pengembangan potensi dan kemampuan ekonomi masyarakat desa pada umumnya untuk meningkatkan kesejahteraan ekonomi dan sosialnya, berperan secara aktif dalam upaya meningkatkan kualitas kehidupan manusia dan masyarakat, memperkokoh perekonomian rakyat sebagai dasar kekuatan dan ketahanan perekonomian nasional dengan BUMDes sebagai pondasinya, berusaha untuk mewujudkan dan mengembangkan perekonomian masyarakat desa dan membantu para masyarakat untuk meningkatkan penghasilan sehingga dapat meningkatkan pendapatan dan kemakmuran masyarakat.

Substansi dan filosofi BUMDes harus dijiwai dengan semangat kebersamaan dan self help sebagai upaya memperkuat aspek ekonomi kelembagaannya. Pada tahap ini, BUMDes akan bergerak seirama dengan upaya meningkatkan sumber-sumber pendapatan asli desa, menggerakkan kegiatan ekonomi masyarakat dimana peran BUMDes sebagai institusi payung dalam menaungi. Upaya ini juga penting dalam kerangka mengurangi peran free-rider yang seringkali meningkatkan biaya transaksi dalam kegiatan ekonomi masyarakat melalui praktek rente (Nurcholis, 2011).

Kabupaten Sinjai memiliki sekitar 125 BUMDes disetiap desa yang tersebar di 16 Kecamatan. Jenis usaha yang dilakukan oleh BUMDes yang ada di Kabupaten Sinjai diantaranya: 1) Simpan pinjam untuk kegiatan usaha tani dan perdagangan, 2) Pengelolaan kios usaha seperti kios pertanian dan kios perdagangan, 3) Pengelolaan air bersih, 4) Pengelolaan pasar, 5) Peternakan, dan 6) Pengelolaan Air Kemasan. BUMDes yang ada di Kabupaten Sinjai memiliki tingkat perkembangan usaha yang berbeda, dimana terbagi menjadi dua kategori, yaitu pada tingkat "Baik" dan "Berjalan". Pada kategori "Baik" terdapat 30 BUMDes sedangkan sisanya 95 BUMDes masih dalam kategori "Berjalan". (Badan Pemberdayaan Masyarakat dan Pemerintahan Desa Kabupaten Sinjai, 2020)

Pembangunan lembaga ekonomi Desa melalui Badan Usaha Milik Desa (BUMDes) di Desa Polewali Kabupaten Sinjai sudah berjalan sebagaimana yang diatur dalam peraturan daerah (PERDA) Nomor 12 Tahun 2011 tentang Pedoman Pembentukan Dan Pengelolaan Badan Usaha Milik Desa (Bumdes) dan disertai peraturan Desa (PERDES) Desa Polewali Nomor 3 Tahun 2015 tentang Pembentukan Badan Usaha Milik Desa (BUMDes).

Salah satu produk unggulan BUMDes di Desa Polewali adalah produk air minum kemasan. Pemilihan jenis usaha BUMDes ini dikarenakan di Desa Polewali potensi air dari perbukitan sangat memungkinkan untuk diolah dan dikelolah sendiri. Apalagi kebutuhan masyarakat baik di Desa Polewali maupun di Desa tetangga, ketergantungan terhadap air kemasan sangat tinggi.

Penelitian ini bertujuan untuk mengetahui sistem pelaksanaan pengelolaan BUMDes Polewali Maju di Desa Polewali Kabupaten Sinjai dan cara meningkatkan pengembahan usaha BUMDes Polewali Maju di Desa Polewali Kabupaten Sinjai

\section{METODE PENELITIAN}

Lokasi penelitian ini dilakukan di Desa Polewali Kabupaten Sinjai. Penelitian ini menggunakan pendekatan deskriptif kualitatif terhadap fenomena sosial yang sedang terjadi. Data yang digunakan dalam penelitian ini adalah data primer dan data sekunder. Menurut Sugiyono (2011) teknik pengumpulan data dilakukan dengan metode observasi, wawancara, studi kepustakaan (Library Research), dan penelusuran data online.

Teknik analisis data pada penelitian ini dilakukan secara cermat dimana data diseleksi mengggunakan teknik analisis data deskriptif yaitu data-data yang telah dihimpun dan dikumpulkan baik primer maupun sekunder, kemudian diambil kesimpulan sebagai jawaban masalah yang diteliti. Pengolahan data diakukan melalui reduksi data, penyajian data dan penarikan kesimpulan dan verifikasi data. Sementara itu kredibilitas data dalam penelitian ini dilakukan melalui perpanjangan pengamatan, meningkatkan ketekunan, triangulasi data, analisis kasus negatif, menggunakan bahan referensi, dan mengadakan member chek.

\section{HASIL DAN PEMBAHASAN}


Badan Usaha Milik Desa (BUMDes) merupakan badan usaha milik desa yang didirikan atas dasar kebutuhan dan potensi desa sebagai upaya peningkatan kesejahteraan masyarakat. Berkenaan dengan perencanaan dan penderiannya, BUMDes dibangun atas prakarsa dan partisipasi masyarakat. BUMDes juga merupakan perwujudan partisipasi masyarakat desa secara keseluruhan, sehingga tidak menciptakan model usaha yang dihegemoni oleh kelompok tertentu ditingkat desa. Siagian (2012) menyatakan BUMDes merupakan salah satu strategi kebijakan untuk menghadirkan institusi negara (Kementrian Desa PDTT) dalam kehidupan bermasyarakat dan bernegara di Desa (selanjutnya disebut Tradisi Berdesa). BUMDes juga merupakan salah satu strategi kebijakan membangun Indonesia dari pinggiran melalui pengembangan usaha ekonomi Desa yang bersifat kolektif. BUMDes merupakan salah satu bentuk kemandirian ekonomi Desa dengan menggerakkan unitunit usaha yang strategis bagi usaha ekonomi kolektif Desa.

\section{Pelaksanaan Pengelolaan BUMDes Desa Polewali Kabupaten Sinjai}

Proses pelaksanaan pembangunan BUMDes Polewali Maju khususnya pada usaha bergerak di bidang usaha air minum kemasan, membutuhkan tahapantahapan khusus. Diantaranya seperti melakukan sosialisasi-sosialisasi kepada seluruh lapisan masyarakat. Kemudian setelah itu jika sudah menjalankan usaha tersebut pemerintah Desa dan BUMDes melakukan pembinaan terhadap tenaga kerja maupun masyarakat yang tergabung. Setelah itu di lanjutkan dengan melakukan monitoring kegiatan yang ada. Tujuannya adalah agar pembangunan usaha ini dapat berjalan dengan baik serta dapat membantu untuk mensejahterakan masyarakat.

Salah satu kegiatan yang dilakukan oleh petugas BUMDes Polewali Maju adalah kegiatan sosialisasi. Proses sosialisasi dilakukan dengan bekerjasama dengan pihak terkait seperti Dinas PMD, Kecamatan, BPD, dan pihak-pihak terkait lainnya. Hal ini dilakukan agar semua proses kegiatan BUMDes dapat berjalan dengan baik. Disamping itu Kepala Desa juga selalu turut andil dalam pelaksanaan sosialisasi tersebut. Dimana akan sangat memudahkan dan meyakinkan kepada masyarakat bahwa program yang dilakukan sangat efektif dan dapat meningkatkan perekonomian masyarakat.

Selain sosialisasi hal penting lainnya adalah melakukan kegiatan pembinaan baik kepada petugas BUMDes maupun kepada masyarakat Desa dimana BUMDes tersebut berdiri. Kegiatan-kegiatan dalam pembinaan dilakukan dengan cara-cara yang sederhana. Seperti melakukan temu wicara kepada masyarakat di setiap RT nya, kemudian melakukan perkumpulanperkumpulan dimana tujuannya agar masyarakat dapat dengan mudah memahami apa yang di sampaikan.

Hal lain yang tidak muncul dalam kegiatan pembinaan di BUMDes Polewali Maju adalah keterlibatan tenaga-tenaga ahli dan professional yang mengerti tentang BUMDes. Tidak ada kegiatan yang dilakukan secara formal untuk melatih para petugas BUMDes tersebut. Padahal idealnya dalam rangka untuk mengembangkan sumber daya petugas BUMDes harusnya dibekali dengan pengetahuan seputar BUMDes. Apalagi dalam konsep pengembangan BUMDes sesuai dengan konteksnya hari ini, setiap petugas BUMDes harus memilki daya kreaktifitas dan inovasi yang tinggi.

Kegiatan lain yang juga dilakukan dalam kegiatan BUMDes Polewali Maju adalah melakukan monitoring terhadap aktifitas BUMDes. Pentingnya kegiatan monitoring terhadap perkembangan hasil produksi air kemasan adalah untuk memastikan progress kegiatan usaha BUMDes tersebut. Kegiatan monitoring dilakukan setiap 3 bulan sekali. Hal ini dilakukan dengan harapan agar supaya kegiatan produksi BUMDes akan semakin berkembang. Selain itu kegiatan monitoring juga dilakukan sebagai bahan acuan bagi BUMDes agar segera mengatasi ketika terjadi masalah baik dalam proses produksi ataupun dalam proses pemasaran. Dan bahkan juga masalah-masalah lainnya yang dapat saja terjadi.

Hasil penelitian ditemukan dilapangan kegiatan monitoring tersebut juga tidak berjalan sebagaimaa semestinya. Mungkin karena kegiatan produksi hanya dilakukan secara temporer, dan kegiatan produksinya hampir tidak teorganisir. Hal tersebut dibenarkan oleh petugas BUMDes Polewali Maju bahwa monitoring tidak dilakukan sebagaiman mestinya, mungkin karena kegiatan BUMDes tidak setiap saat beroperasi. Hasil dari kegiatan monitoring tersebut kemudian menjadi acuan dalam melaksanakan kegiatan evaluasi. Dalam proses evaluasi pihak BUMDes membuat laporan-laporan disetiap tiga bulan/triwulan. Contohnya laporan keuangan, laporan hasil penjualan, laporan jumlah keuntungan serta kerugian yang diperoleh, dan juga laporan yang lainnya. Tujuannya agar dapat mengetahui apakah ada peningkatan hasil usaha atau tidak ada.

Tingkat kemajuan dari usaha produksi air minum kemasan sudah berkembang dengan baik. Walaupun memang belum mencapai target yang diinginkan. Namun seiring berjalannya waktu usaha tersebut diharapkan akan semakin maju dan berkembang. Sehingga dapat meningkatkan PAD Desa dan secara tidak langsung dapat membantu masyarakat miskin disekitar.

Dalam mendirikan sebuah usaha, tentu ada faktorfaktor pendukung yang membantu proses pembangunan tersebut. Begitu pula dalam proses pembangunan usaha produksi air kemasan. Ada beberapa hal yang menjadi faktor pendukung dari proses pembangunan usaha air minum kemasan di BUMDes Polewali Maju. Diantaranya kondisi infrastruktur yang baik, sarana memadai, tingkat keahlian petugas BUMDes, dan dukungan dari pemerintah desa maupun pemerintah daerah. Sehingga pelaksanaan kegiatan produksi air kemasan BUMDes Polewali Maju dapat berjalan sesuai dengan perencanaan serta dapat meningkatkan kesejahteraan perekonomian masyarakat di Desa Polewali. 
Konsep Meningkatkan Pengembangan Usaha BUMDes di Desa Polewali

Pembangunan usaha air minum kemasan merupakan pilihan yang tepat dalam proses meningkatkan kesejahteraan masyarakat di Desa Polewali. Hal tersebut dapat dilihat dari keseriusan pemerintah Desa dalam menjalankan program, kemudian manfaat yang didapat jika program tersebut sudah berjalan.

Dalam usaha pembangunan BUMDes Polewali Maju dengan jenis usaha air kemasan tidaklah mudah. Karena pemerintah Desa Polewali harus mengatur strategistrategi agar dana yang ada tidak mengganggu kebutuhan lainnya atau pembangunan lainnya yang ada di Desa Polewali. Karena dana yang yang digunakan untuk mendai BUMDes tersebut bersumber dari APBDes, ADD, dan DD dari Desa Polewali. Hal tersebut merupakan suatu bentuk partisipasi Desa dalam usaha pembangunan air minum kemasan dalam upaya pemberdayaan serta peningkatan kesejahteraan masyarakat.

Setelah proses pendanaan telah dilkukan maka selajutnya adalah proses perencanaan dan penjadwalan pembangunan pabrik mulai dari persiapan lahan, dan penyusunan tenaga kerja, telah diperhitungkan secara rinci. Kemudian dalam proses pembangunan pabrik juga tidak lepas dari campur tangan pihak ketiga selaku tenaga ahli, kemudian masyarakat, dan juga lembaga-lembaga yang ada di Desa Polewali. Tujuannya adalah agar seluruh komponen masyarakat punya rasa memiliki akan adanya pabrik ini. Dan memiliki rasa peduli dengan adanya program usaha air minum kemasan di BUMDes Polewali Maju.

Selanjutnya adalah membangun hubungan kemitraan atau kerjasama yang dilakukan terkait dengan proses pembangunan usaha air minum kemasan sampai kepada pemasaran. Namun dari hasil penelitian yang peneliti lakukan sampai pada saat peneliti melakukan penelitian BUMDes Polewali Maju belum melakukan kerjasama kemitraan dengan pihak manapun. Padahal peluang untuk melakukan kerjasama tersebut sangat besar khususnya kepada pemerintah Kabupaten Sinjai karna pemerintah Sinjai sendiri sudah merencanakan program BUMDes membangun Sinjai. Sebagai contoh misalnya dalam konsep manajemen pemasaran BUMDes Polewali Maju bisa membuat Memorandum Of Understanding (MoU) dengan Pemkab Sinjai yang isinya memuat tentang seluruh kegiatan pemerintahan dilingkup Pemkab Sinjai harus menggunakan produk hasil BUMDes salah satunya adalah produk air minum kemasan hasil BUMDes Polewali Maju.

Namun hal tersebut tidak dilakukan baik oleh pemerintah Desa Polewali maupun oleh pengelolah BUMDes Polewali Maju. Saat peneliti konfirmasi tentang hal tersebut jawabannya sangat politis bahwa hal tersebut juga dipikirkan oleh pemerintah desa bersama dengan petugas BUMDes di desa Polewali. Selain masalah membangun kemitraan, juga hal yang penting adalah proses penentuan tenaga kerja. Menurut direktur BUMDes Polewali Maju hal tersebut sudah dilakukan dengan tahapan yang sangat baik., termasuk merekrut orang-orang yang tidak merupakan bagian dari perangkat Desa. Mereka juga yang terpilih adalah orang-orang yang dianggap memiliki kreaktifitas yang cukup baik.

Selain itu masalah pelibatan masyarakat dalam kegiatan BUMDes Polewali Maju dalam hal ini memberdayakan masyarakat sekitar juga sangat minim. Dan hal ini diakui pula oleh direktur BUMDes Polewali Maju yang dalam pernyataannya kepada peneliti mengungkapkan bahwa hampir semua perlengkapan produksi pembuatan air minum kemasan di BUMDes Polewali Maju didatangkan dari luar atau perusahan sebagai pihak ketiga.

Disisi lain hal ini memang berat karna perlengkapan produksi tersebut adalah berasal dari hasil daur ulang yang biasnya membutuhkan alat teknologi tertentu. Sehingga pada posisi ini tentu masyarakat tidak akan mungkin dilibatkan. Salah satu yang dapat dilakukan adalah melibatkan masyarakat untuk mensosialisasikan sekaligus memasarkan hasil produksi BUMDes kepada khalayak umum. Hanya saja hal tersebut dapat dilakukan jika permintaan terhadap hasil produksi BUMDes sudah diatas rata-rata pemasaran.

Sistem Pelaksanaan Pengelolaan BUMDes Polewali Maju sudah dilakukan dengan baik. Hal ini jika didasarkan kepada sistem pelaksanaan pendirian BUMDes. Di Desa Polewali dalam mendirikan BUMDes didasarkan kepada perauran perundang-undangan yang berlaku. Mulai daripada proses pembentukan kelembagaan sampai kepada ketersidaan sarana dan prasarana. Dalam penentuan kelembagaan BUMDes Polewali Maju sudah tidak melibatkan perangkat Desa seperti yang dipersyaratkan didalam peraturan yang mengatur tentang pembentukan BUMDes. Ketersediaan sarana dan prasarana juga sudah dipenuhi meskipun belum memadai sesuai dengan kebutuhan produksi BUMDes. Bentuk kegiatan BUMDes Polewali Maju yang dilakukan adalah produksi air kemasan.

Cara Meningkatkan Pengembangan Usaha BUMDes Polewali Maju dilakukan dalam beberapa strategi yang dilakukan oleh pengurus BUMDes bersama dengan pemerintah desa setempat. Keterlibatan pihak-pihak yang terkait dengan BUMDes sudah dilakukan. Ada beberapa langka yang dilakukan dalam rangka mengembangkan usaha BUMDes Polewali Maju di Desa Polewali yaitu bantuan permodalan dari pemerintah Desa, kegiatan pendampingan dan pelatihan dan pemberdayaan masyarakat sebagai prasyarat keterlibtan masyarakat. Dalamhal bantuan permodalan yang diberikan oleh pemerintah Desa Polewali sudah dilakukan namun dari jumlah belum memadai jika dibandingkan dengan beban kegiatan BUMDes yang harus dibiayai. Sementara kegiatan pelatihan dan pendampingan juga sudah dilakukan namun belum efektif dalam pelaksanaannya. Akibatnya produktifitas petugas BUMDes yang diharapkan belum memberikan kontribusi yang besar bagi pengembangan BUMDes. Hal lain yang juga penting adalah kerjasama kemitraan dengan para pihak yang 
terkait dengan upaya pengembangan usaha BUMDes. Kerjasama kemitraan ini berfungsi sebagai strategi dalam rangka memasarkan hasil-hasil produksi BUMDes. Sebagai contoh BUMDes Polewali Maju di Desa Polewali yang memproduksi air minum kemasan seharusnya dikerjasamakan dengan pemerintah dalam pemasarannya dimana setiap instansi pemerintah yang melaksanakan kegiatan rapat atau pertemuan harus menggunakan air minum kemasan hasil produksi BUMDes Polewali Maju.

\section{KESIMPULAN}

Hasil penelitian dapat disimpulkan bahwa bahwa pelaksanaan pengelolaan BUMDes di Desa Polewali sudah dilakukan sesuai dengan peraturan yang berlaku dan tata kerja yang telah dibuat bersama antar seluruh pihak terkait dengan BUMDes Polewali Maju. Penentuan kelembagaan BUMDes juga dilakukan dengan baik karna sudah tidak melibatkan perangkat Desa. Hanya saja kelegkapansaran dan prasaranan BUMDes masih sangat terbatas. Sementara berkaitan dengan cara pengembangan usaha BUMDes masih belum produktif, seperti kerja sama dengan para pihak, pelatihan dan pendampingan yang minim.

\section{DAFTAR PUSTAKA}

Buchory, 2005, Kewirausahaan Untuk Mahasiswa dan Umum, Bandung, Alfabeta.

Coristya Berlian Ramadana, 2016 Keberadaan Usaha Milik Desa (BUMDES) dalam Pembangunan Perekonomian Desa. Dalam jurnal Administrasi Publik (JAP).

Depdiknas. 2013 Kamus Besar Bahasa Indonesia pusat bahasa. Cet Kelima. Jakarta: PT Gramedia. Yogyakarta: Pustaka Pelajar.

Dess \& Lumpkin dalam Kuncoro, 2005. Strategi Bagaimana Meraih Keunggulan Kompetitif. Erlangga. Jakarta.

Dess dan Lumpkin dalam Kuncoro 2006. Ekonomi Pembangunan. Penerbit Salemba Empat, Jakarta. Tambunan, T.TH. 2012

Dess Gregory G dan Miller Alex dalam Buchory, 2005. Pemberdayaan Masyarakat: Konsep Pembangunan yang Berakar pada Masyarakat.

Hanif Nurcholis, 2011. Pertumbuhan Dan Penyelenggaraan Pemerintah Desa, Penerbit, erlangga

Ife, Jim dan Tesoriero, Frank. 2008. Community Development: Alternatif Pengembangan Masyarakat di Era Globalisasi. Yogyakarta: Penerbit Pustaka Pelajar.

James Brian Quinn, Mintzberg, Lampel, Quinn, Ghoshal. 2003. The Strategy Process Londen: prentice hall internasinal.

Mintzhberg dalam Budhita. 2004. Democracy and Its Critics.New Haven Conn: Yale University Press.
Rangkuti, 2005. Pemberdayaan Masyarakat dalam Pengembangan Kehidupan Berdemokrasi di Indonesia.

Ridwan, R., Hamka, H., \& Nurkaidah, N. 2019. Efektifitas Implementasi Peraturan Bupati Nomor 59 Tahun 2015 Tentang Pengelolaan Keuangan Desa Di Kabupaten Sinjai. Jurnal Paradigma Administrasi Negara, 1(2), 24-30

Rizka Hayyuna and Ratih Nur Pratiwi. 2016. Pemberdayaan Masyarakat dalam Pengembangan Kehidupan Berdemokrasi di Indonesia.

Seyadi, 2003. Pemberdayaan, Kebijakan, dan Implementasi. Jakarta: Centre For Strategic and International Studies.

Siagian. 2012, Manajement Sumber Daya Manusia. Jakarta: Bumu Aksara.

Stephanie K. Marrus. 2010, Strategic management in action. PT. gramedia pustaka utama, Jakarta.

Sugiyono, 2011. Metode Penelitian Pendidikan: Pendekatan Kuantitatif, Kualitatif, dan R \& D. Bandung: Alfabeta.

Tampubolon, Mangatas. 2006. Pendidikan Pola Pemberdayaan Masyarakat Dan Michael Porter 1992. Pembangunan Dilema dan Tantangan. Yogyakarta: Pustaka Pelajar.

Undang-Undang 32 tahun 2004 tentang Pemerintahan Daerah

Undang-Undang Nomor 22 Tahun 1999 tentang Pemerintahan Daerah yang kemudian berubah menjadi UU Nomor 32 Tahun 2004 dan kemudian terakhir diperbaharui melalui UU Nomor 23 Tahun 2014 tentang Pemerintahan Daerah.

Undang-Undang, UU 22/1999 dan Peraturan Pemerintah (PP) No.71 Tahun 2005 Tentang Desa. 